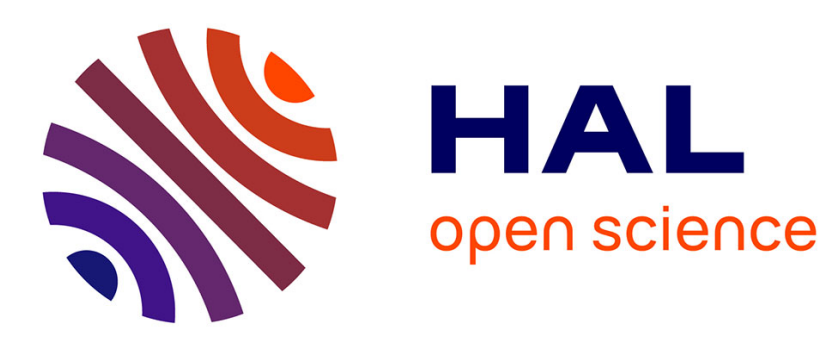

\title{
Plasticity of tree root system structure in contrasting soil materials and environmental conditions
}

\author{
C. Zanetti, M. Vennetier, P. Mériaux, M. Provensal
}

\section{To cite this version:}

C. Zanetti, M. Vennetier, P. Mériaux, M. Provensal. Plasticity of tree root system structure in contrasting soil materials and environmental conditions. Plant and Soil, 2015, 387 (1-2), pp.21-35. $10.1007 / \mathrm{s} 11104-014-2253-\mathrm{z}$. hal-01357133

\section{HAL Id: hal-01357133 \\ https://hal.science/hal-01357133}

Submitted on 29 Aug 2016

HAL is a multi-disciplinary open access archive for the deposit and dissemination of scientific research documents, whether they are published or not. The documents may come from teaching and research institutions in France or abroad, or from public or private research centers.
L'archive ouverte pluridisciplinaire HAL, est destinée au dépôt et à la diffusion de documents scientifiques de niveau recherche, publiés ou non, émanant des établissements d'enseignement et de recherche français ou étrangers, des laboratoires publics ou privés. 


\title{
Plasticity of tree root system structure in contrasting soil materials and environmental conditions \\ Caroline Zanetti $*{ }^{1 a+2}$, Michel Vennetier ${ }^{1 b+3}$, Patrice Mériaux $^{1 a+3}$, Mireille Provansal ${ }^{4}$
}

\author{
${ }^{1 a}$ Irstea, UR OHAX Ouvrages hydrauliques et hydrologie, Le Tholonet Aix-en-Provence, F-13182, France \\ ${ }^{1 b}$ Irstea, UR EMAX Ecosystèmes méditerranéens et risques, Le Tholonet Aix-en-Provence, F-13182, France \\ ${ }^{2}$ ARBEAUSOLutions, 100 impasse des Houillères, 13590 Meyreuil, France \\ ${ }^{3}$ ECCOREV FR 3098, Université Aix-Marseille, France \\ 4 CEREGE, Europôle de l'Arbois, BP 80, 13545 Aix-en-Provence cedex 4 \\ "Corresponding author: c.zanetti@ arbeausolutions.fr (+33 (0)6 821855 43)
}

\begin{abstract}
Background and Aims

Tree root system structure and development are difficult to assess and poorly understood in natural conditions because of soil heterogeneity and the difficulty in extracting mature tree root systems without damaging them. The purpose of this study was to understand root system development plasticity according to biological and physical parameters: species tree age and size, soil material, water availability, slope angle, and climate.

Methods

Two hundred and forty-three mature trees from twelve species were uprooted from homogeneous French dikes fills. Root system structure (root number and size, root system span, depth and volume) was compared between two contrasting soil materials: fine and coarse.

$\underline{\text { Results }}$

Tree species had little influence on root system structure: all root system types and root size could be found for most of the species according to site conditions. Heart root systems were limited to fine material while mixed and tap root systems were found on coarse material. In coarse materials, trees developed few but rather large roots $(>5 \mathrm{~cm}$ in diameter and $>4 \mathrm{~m}$ in length). In fine materials, root systems had three times more roots but they were $40 \%$ smaller and shorter. Roots were $20 \%$ more numerous and $65 \%$ larger on the downslope side due to water availability at dike or riverbank toe.

Conclusion

Root system structure was mainly influenced by soil material and water availability and far less by tree species. Tree root systems are opportunistic in developing in the direction where water and nutrients are plentiful: whatever the species, predicting its dimensions and structure requires a thorough investigation of soil and other environmental conditions. This study gives a new insight in root development: it will help predict tree root growth in various environments and particularly on dikes.
\end{abstract}

Key Words: tree root system structure; root number; root size; root distribution; trees on dikes

\section{1 - Introduction}

Assessing the structure of tree root systems (root number, size and distribution, root system span, depth and volume) is a difficult task, and their relationship with environmental conditions has been poorly investigated for large adult trees. For many species and environments, research was limited to root biomass distribution according to the distance from the stump in depth or laterally (Plourde et al., 2009). Indeed, modelling root systems is not easy, because of their complexity and of the multiple parameters influencing their development and structure. However, some models have been developed and implemented for cultivated plants and fruit trees (Jourdan et al., 1997; Vercambre et al., 2003) because roots can be fully extracted and measured in agricultural soils. Such an extraction is far more difficult for large trees because of the span and depth of their root systems (Canadell et al., 1996; Stone et al., 1991), except in very favourable conditions, such as deep, homogeneous soils with a fine texture (Danjon et al., 2005; Vyskot, 1976). This is why in most cases, studies on tree root system architecture deal with small and young trees. One of the more thorough investigations of root system development for many forest tree species in various environments was performed by Köstler et al. (1968) but data on root system global structure according to soil material are scarce. We particularly lack descriptions of root systems on coarse materials (Devine et al., 2005). Tree root system and its development processes are partly known by studies carried out in specific contexts, for example in planted forests (Plourde et al., 2009), in agroforestry systems (Akinnifesi et al., 1999), after storms or avalanches on uprooted systems (Danjon et al., 2005; Nicoll et al., 2006b), in sand dunes (Wagner et al., 2011) or alluvial environment (Rood et al., 2011), and on unstable or steep slopes (Reubens et al., 2007). Some specific methods and tools were progressively developed to accurately describe and model roots and root systems (Armengaud et al., 2009; Danjon et al., 2008; Tobin et al., 2007). 
Tree root system classification is generally defined by its global structure (Atger et al., 1994) and its adaptation to the environment (Fitter et al., 1991; Fitter, 1994; Foussadier, 2003). Root systems are differentiated according to their morphology and main types of roots (Sutton et al., 1983). The three most used groups (Köstler et al., 1968) are: (i) the heart root system, which roots occupy the whole space around the stump, with no preferential root angle, (ii) the plate-shape root system, also called the shallow root system, in which all roots remain superficial, and (iii) the taproot root system in which one single or a few large vertical roots dominate. Mixed root systems combining plate-shape and taproot systems are frequent, with two dominant root angles (vertical and horizontal) and no or few oblique roots.

Root system structure is generally considered as a trade-off between the genetic potential of a species and its plasticity in allowing adaptation to local environment (Köstler et al., 1968). Variations in soil conditions are known to drive root growth at local scale (Desnos, 2008; George et al., 1997; Soar et al., 2007), as well as at root system scale (Schenk et al., 2005). Therefore, strong soil constraints should result in at least partly similar root systems structure for various tree species.

Hundreds of thousands of $\mathrm{km}$ of dikes are found along rivers and canals throughout the world, in addition to countless earth dams built for irrigation, flood control, fishing, tourism, landscape or electricity. The presence of mature trees and even forest stands on such fills is common. Very few scientific articles have been published on tree root development in earth dikes or dams (Corcoran, 2009; Haselsteiner, 2010; Shields et al., 1992). Recently, dike managers in France and other countries started removing these trees, giving us the opportunity to study a large number of tree root systems in contrasting environments.

This study aimed at comparing the structure and development of tree root system according to two main soil materials (fine and coarse), taking advantage of a study of root system structure and growth in earth dikes and dams (Zanetti 2010). The goal was to relate root system structure to biological and physical parameters: species, tree age and size, water availability, soil material, slope angle and climate. We hypothesized that due to the contrasting physical constraints between the two types of soil, particularly for water availability and nutrients, tree root systems would adapt their morphology to environmental constraints independently from tree species and that resulting root systems would be very different in terms of root size, number and distribution for a given species.

\section{2 - Material and methods}

\section{1 - Study Sites}

Study sites (Fig. 1) were distributed along a wide range of climates from dry and hot Mediterranean plains to humid and cold mountains (Table 1). Access to water resources for trees growing on the dikes varied with fill size and with the distance between the stump and the canal, river or dike toe. In this study, canal dikes and dams with a permanent water head were twice to three times larger than flood protection dikes.

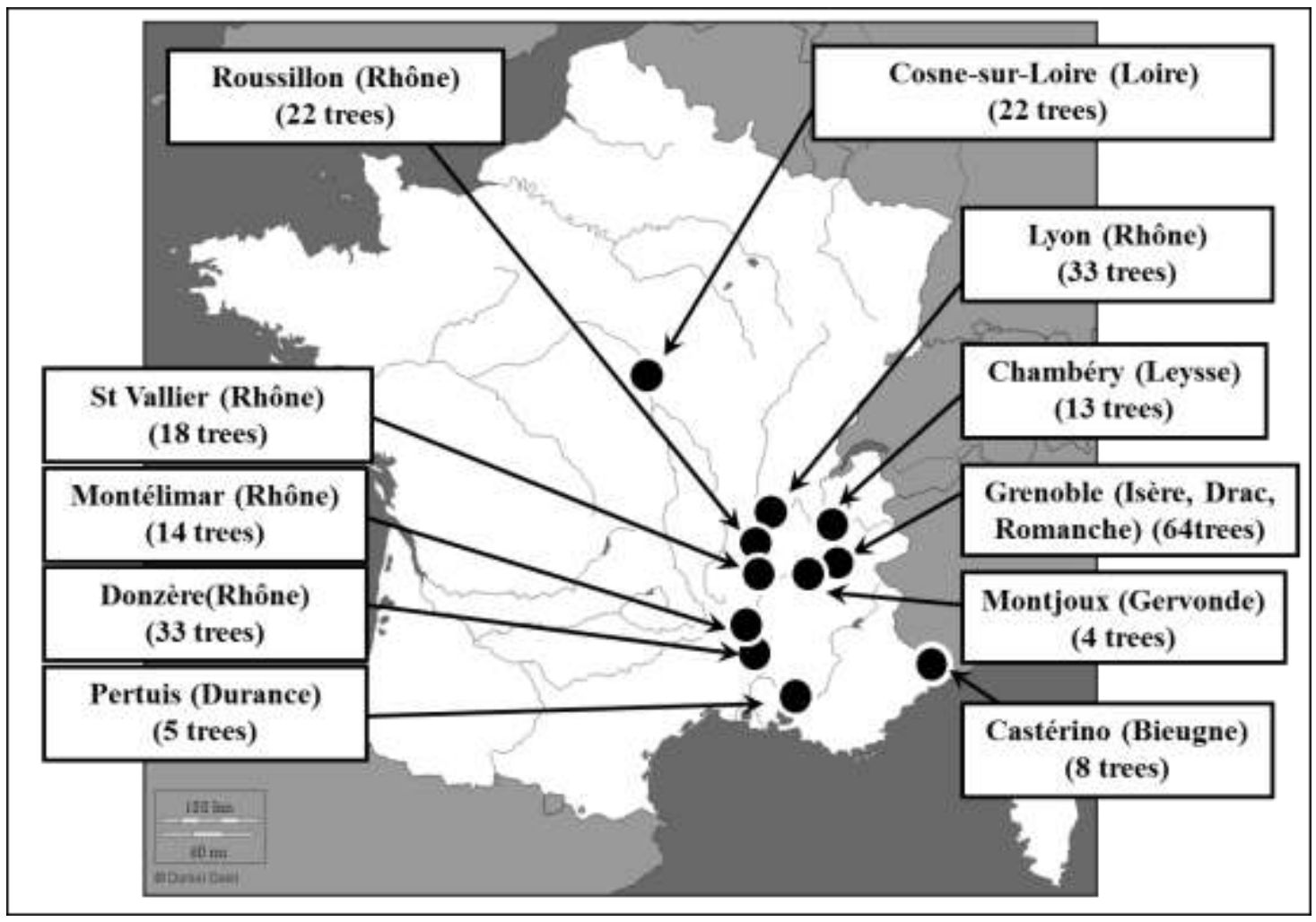

Figure 1: Study sites (rivers) and number of trees per site 
Table 1 : Characteristics or the 8 study sites

\begin{tabular}{|c|c|c|c|c|c|c|c|c|}
\hline $\begin{array}{c}\text { Study sites } \\
\text { characteristics }\end{array}$ & $\begin{array}{l}\text { Montélimar, } \\
\text { Donzère }\end{array}$ & $\begin{array}{l}\text { Lyon, } \\
\text { Roussillon, } \\
\text { St Vallier }\end{array}$ & Grenoble & $\begin{array}{l}\text { Cosne-sur- } \\
\text { Loire }\end{array}$ & Pertuis & Castérino & Chambéry & Montjoux \\
\hline River & Rhône & Rhône & $\begin{array}{l}\text { Isère, Drac } \\
\text { Romanche }\end{array}$ & Loire & Durance & Bieugne & Leysse & Gervonde \\
\hline Altitude (m) & 85 & 200 & 250 & 150 & 200 & 1500 & 270 & 254 \\
\hline Rainfall (mm/yr) & 700 & 800 & 934 & 690 & 640 & 1200 & 1136 & 946 \\
\hline $\begin{array}{l}\text { Temperature }\left({ }^{\circ} \mathrm{C}\right) \\
\text { Min/Mean/Max }\end{array}$ & $9.2 / 13.8 / 18.5$ & $8.1 / 12.8 / 17$ & $6.3 / 12 / 16.2$ & $\begin{array}{c}6.3 / 10.1 / 15 \\
4\end{array}$ & $7.2 / 13 / 18.8$ & $0 / 6.1 / 12.6$ & $6.7 / 12 / 18$ & $6.6 / 10.6 / 17$ \\
\hline Type of dike & Canal & Canal & $\begin{array}{c}\text { Flood } \\
\text { protection }\end{array}$ & $\begin{array}{c}\text { Flood } \\
\text { protection }\end{array}$ & $\begin{array}{c}\text { Flood } \\
\text { protection }\end{array}$ & $\begin{array}{c}\text { Flood } \\
\text { protection }\end{array}$ & $\begin{array}{c}\text { Flood } \\
\text { protection }\end{array}$ & Dam \\
\hline Water head & Permanent & Permanent & Temporary & Temporary & Temporary & Temporary & Temporary & Permanent \\
\hline $\begin{array}{l}\text { Dike dimension (m) } \\
\text { (Height / Width) }\end{array}$ & $10 / 100$ & $\begin{array}{l}8-12 / \\
80-100\end{array}$ & $5 / 20$ & $7 / 30$ & $4 / 15$ & $4 / 10$ & $3 / 15$ & $10 / 50$ \\
\hline Fill slope & $20 \%$ & $20 \%$ & $40-60 \%$ & $40-60 \%$ & $40-60 \%$ & $40-60 \%$ & $40-60 \%$ & $20 \%$ \\
\hline Studied species & $\begin{array}{l}\text { Oak, Locust, } \\
\text { Poplar }\end{array}$ & $\begin{array}{c}\text { Oak, Locust, } \\
\text { Poplar, Ash, } \\
\text { Maple, } \\
\text { Willow, Adler }\end{array}$ & $\begin{array}{c}\text { Oak, Locust, } \\
\text { Poplar, Ash, } \\
\text { Willow }\end{array}$ & $\begin{array}{l}\text { Oak, Locust, } \\
\text { Poplar, Ash }\end{array}$ & Poplar, Oak & $\begin{array}{c}\text { Larch, Scots } \\
\text { pine }\end{array}$ & $\begin{array}{c}\text { Poplar, Ash, } \\
\text { Willow, } \\
\text { Adler }\end{array}$ & Poplar, Ash \\
\hline
\end{tabular}

Dikes or their sub-sections were split into two groups according to fill material, coarse and fine. Coarse materials (dominant particle size between $63 \mathrm{~mm}$ to $0.63 \mathrm{~mm}$ ) correspond to the stony to gravely-sandy ones according to GTR NFP 11-300 norm, and fine materials (dominant particle size between $0.63 \mathrm{~mm}$ and $0.002 \mathrm{~mm}$ ) include medium and fine sand, silt, and clay (Zanetti 2010).

Tree sampling design included five criteria: tree species, size, age, position on the dike or dam (crown, toe, lower, middle or upper slope), and soil material (coarse or fine). Twelve species frequently growing on European dikes were studied (table 1): oaks (Quercus ilex L. and Q. pubescens Willd.), maples (Acer campestris L. and A. negundo L.), ash (Fraxinus excelsior L.), poplars (Populus nigra L.and P. alba, L.), locust (Robinia pseudo-acacia L.), willow (Salix alba L.) and alder (Alnus glutinosa L.) in low elevation sites, larch (Larix decidua Mill.) and Scots pine (Pinus sylvestris L.) in mountains.

A total of 243 root systems of mature trees were extracted. Mature means that most of these trees were not far from the maximum height they can reach on studied sites. The study was divided into two phases. In the first, exploratory phase, 87 tree root systems were described in broad terms (global structure, span, size, direction and depth of large roots [proximal diameter $>5 \mathrm{~cm}$ ], root number, distinctive features). In the main study phase, the remaining systems (156), were described in the same way together with accurate measures of individual roots.

The comparisons between the two types of material were computed only for 191 trees growing on homogeneous materials after exclusion of heterogeneous sites and root systems severely constrained by artificial obstacles (masonry, rockfill, lining or wall).

\section{2 - Root system extraction}

At the start of sampling, the tree characteristics were noted: tree base diameter (TBD), position on the fill, and side (river-canal side or landside). Then the selected trees were cut at one metre from the base to allow slinging them up.

Root system excavation was performed in several stages: (1) superficial roots were first free and bared, followed by progressively deeper roots, with a mechanical shovel and by hand, from the stump towards the periphery and when possible up to their tip (limit: $0.2 \mathrm{~cm}$ in diameter). Once the stump had been cleared from ground materials as much as possible, it was slowly lifted in a sling to observe remaining deep and vertical roots and finally fully uprooted. If some large roots remained in the soil at that stage, they were extracted immediately. This excavation method was used because of the great number and large size of studied trees. It was impossible in many cases to remove all material around root systems, particularly very coarse material, using water or compressed air. In many cases, we dug throughout the whole fill down to the foundation or to the natural soil, which allowed an accurate measurement of the position and distance from the stump to available resources such as a water table or buried organic layers. Tree age was obtained by counting tree rings on the stump, or on the main roots for coppiced trees. 
Soil samples were collected in the excavation hole at the level of each tree and for each different layer. After separation and volume measurement of the largest blocks and stones, grain size distribution was determined by wet and dry screening (screens $20 \mathrm{~mm}$ to $80 \mu \mathrm{m}$ - French norm 94-056 / International norm ISO 14688) and sedimentation analysis (French norm 94-057 / International Norm ISO 14688). These materials could be clearly split into coarse and fine types (Zanetti 2010); no site with intermediate material was considered in this study.

\section{3 - Root systems measurements}

During the excavation process, the root structure was described and measured (root number, orientation, proximal diameter and length), photographed, and drawn. Proximal diameter is the initial diameter at root connection with the stump or another root. Root orientation was noted according to the slope: height sectors of 45 degrees each, four upwards and four downwards. Vertical angle was noted according to soil surface: parallel, oblique or vertical. When roots had to be cut during extraction, their position on the stump was spotted, their direction and angle were noted and they were kept aside for later measurement.

After the extraction, stumps were stored upside down. Root number was counted separately for the upward and downward side when trees were growing on a slope. We counted only root larger than $2 \mathrm{~cm}$ in diameter at a distance of $1 \mathrm{~m}$ from the stump periphery. This distance was chosen (1) to eliminate the zone of rapid taper (Eis, 1974), linked to buttresses and the many anastomosis present close to the stump of large trees, and (2) to take fast changes in root orientation into account, these changes being common in this first meter. Roots with a proximal diameter of more than $5 \mathrm{~cm}$ were considered as large roots. All vertical roots were counted and measured separately. Root system volume was computed according to the width and depth of coarse roots.

\section{4 - Statistical analyses}

Root proximal diameter (mean and maximum), root length and root number, were computed for each soil material, root system type, and species. Their correlation with tree base diameter (TBD) was computed. On each material, results were successively computed for all trees and for three classes of TBD, common to both soil materials: small, intermediate and medium size trees corresponding respectively to TBD of 25-35 cm, 35-45 cm and 45-55 cm. Only a few large trees (over $55 \mathrm{~cm}$ ) were found on coarse material so it was not possible to make comparisons with fine material for this class. Because of low numbers in certain TBD classes for some species, multiple comparisons between species were possible only for small trees on coarse material and medium to large trees on fine material. The correlation between root length and root proximal diameter was computed only for entire roots. Root size and number per material, root system type, root orientation or species were compared by analysis of variance in the case of normal distributions, or a Kruskal-Wallis test followed by a Nemenyi test (Nemenyi, 1963) in the case of non-normal distributions. The number of roots per orientation (upwards/downwards) was compared with a pairwise nonparametric signed ranks test. Statistics on root diameter were computed with and without large vertical roots (taproots) to test the possible impact of this particular type of roots.

\section{3 - Results}

\section{1 - Root system type according to soil material, species and position on the fill}

Four root system types were found (Fig. 2): shallow (2a), heart (2b), mixed (2c) and tap root system (2d). While heart root systems were limited to fine material, mixed root systems developed mainly (96\%) on coarse material. Shallow root systems were found on both materials. Only four tap root systems were observed, all of them on coarse material (Fig. 3).

The distribution of root system types by soil material for individual species or genera was consistent with the general trend (Table 2). When they were found on both materials, none of the studied species or genus developed a specific root system structure. Except for alder, which was always found very close to canals or rivers, all of them presented at least two out of the four root system types, and many of them (e.g. poplars, locust, oaks, willow and ash) had three to four types.

On large dikes made of coarse material, root systems were mainly of the shallow type, and less than $50 \mathrm{~cm}$ in depth, located on the crown and the upper part of the slope (75-95\%). Among these shallow root systems, many had a short $(<50 \mathrm{~cm})$ and weak vertical root corresponding to a dead or aborted taproot. Root systems were mostly of mixed or taproot types in the middle and the lower part of the slope while all types except the heart root system were found at the dike or dam toe. On large dikes made of fine material, the heart root system type was found at all positions and the shallow root system was found only at the dike toe. 
Zanetti C., Vennetier M., Mériaux, Provansal M. (in press). Plasticity of tree root system structure in contrasting soil materials and environmental conditions. Plant and Soil. On line 2014; DOI: 10.1007/s11104-014-2272-9

Table 2: Number of sampled trees per root system type according to soil material for each species or genus.

\begin{tabular}{|c|c|c|c|c|c|c|c|c|c|}
\hline & \multicolumn{2}{|c|}{ Shallow } & \multicolumn{2}{|c|}{ Mixed } & \multicolumn{2}{|c|}{ Taproot } & \multicolumn{2}{|c|}{ Heart } & \multirow[t]{2}{*}{$\begin{array}{c}\text { Total root } \\
\text { system number }\end{array}$} \\
\hline & Coarse & Fine & Coarse & Fine & Coarse & Fine & Coarse & Fine & \\
\hline Locust & 18 & 0 & 18 & 0 & 0 & 0 & 0 & 8 & 44 \\
\hline Poplar & 14 & 3 & 29 & 0 & 3 & 0 & 0 & 10 & 59 \\
\hline Oak & 2 & 0 & 11 & 0 & 1 & 0 & 0 & 8 & 22 \\
\hline Ash & 1 & 7 & 6 & 0 & 0 & 0 & 0 & 6 & 20 \\
\hline Maple & 2 & 2 & 0 & 0 & 0 & 0 & 0 & 4 & 8 \\
\hline Willow & 1 & 5 & 5 & 3 & 0 & 0 & 0 & 2 & 16 \\
\hline Alder & 0 & 5 & 4 & 0 & 0 & 0 & 0 & 0 & 9 \\
\hline Scots pine & 2 & 0 & 4 & 0 & 0 & 0 & 0 & 0 & 6 \\
\hline Larch & 0 & 0 & 7 & 0 & 0 & 0 & 0 & 0 & 7 \\
\hline $\begin{array}{l}\text { Total root system } \\
\text { number }\end{array}$ & 40 & 22 & 84 & 3 & 4 & 0 & 0 & 38 & 191 \\
\hline
\end{tabular}

$\mathrm{C}=$ Coarse material, $\mathrm{F}=$ Fine material 
Figure 2:

The four types of root systems

(a) Shallow root system

Maple at dike toe

Loire River

Fine material

(b) Heart root system

Oak at dike slope middle

Loire river

Fine material

(c) Mixed root system

Poplar at dike toe

Rhône River

Coarse material

(d) Tap root system

Poplar at dike slope middle

Rhône River

Coarse material
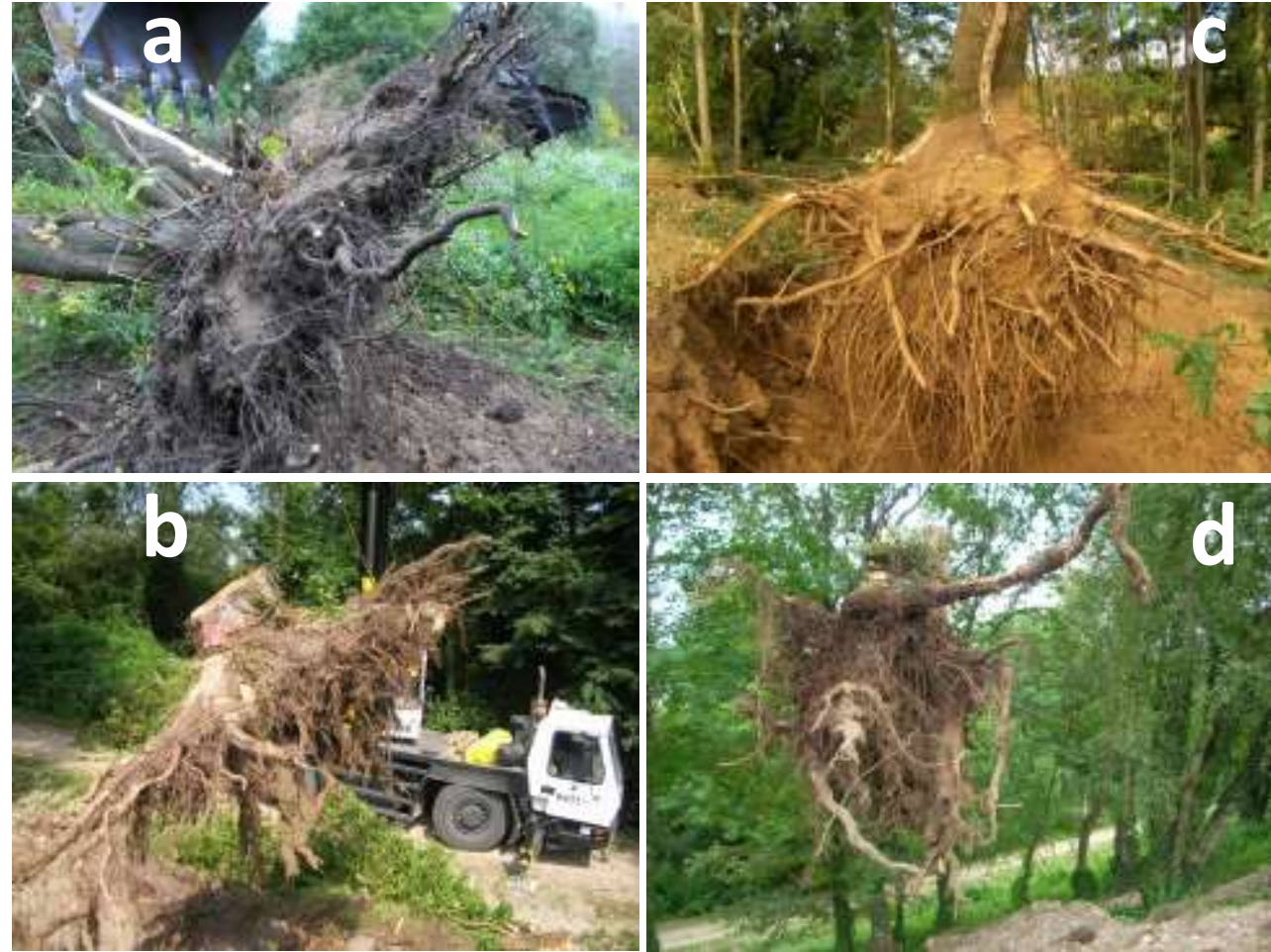

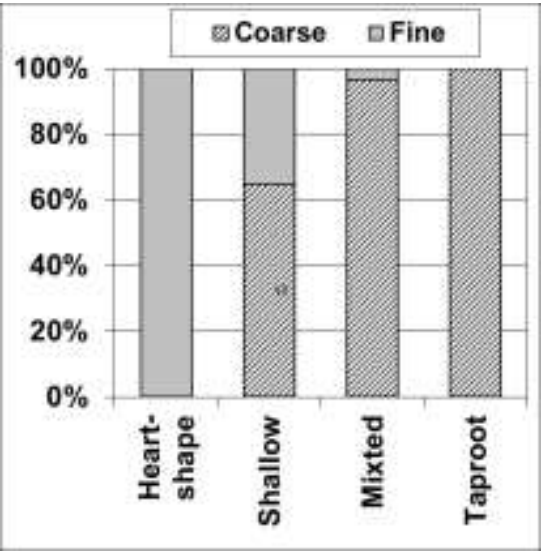

Figure 3: Distribution of the four root system structures (all species) according to material

Heart root systems are found only on fine material, shallow root systems on both materials, mixed root systems mainly on coarse material, tap root systems only on coarse material.

\section{2 - Number of roots per root system}

The number of roots per root system depended on soil material and partly on tree base diameter (TBD) and root system type (Table 3a and Fig. 4). Taking all species and root system types together, roots were three to four times more numerous in fine material than in coarse material. The difference was significant for all TBD classes $(\mathrm{P}<0.001$; table $3 . \mathrm{a})$, and increased with TBD. In fine material, the root number was always over 80 for trees with TBD over $25 \mathrm{~cm}$, and increased with TBD, reaching more than 300 for the largest trees. In coarse material, root number varied from 25 to 60, and no trend was found with TBD over $20 \mathrm{~cm}$ even for the largest trees.

No differences in root number were found between root system types in fine material. Conversely, root number was higher for mixed and tap root systems than for shallow root systems in coarse material $(\mathrm{P}<0.01)$ for small and intermediate TBD classes. Within the same TBD classes, roots of shallow root systems were three times more numerous in fine than in coarse material $(\mathrm{P}<0.001)$, matching the general trend.

For a given type of material and for the same class of TBD, no significant differences in root number were found between species (Table 3b), except for locust which had a slightly and significantly higher number of roots than other species but only on coarse material.

\section{3 - Root size}

As a whole (Table 3c), although sampled trees were larger on fine material, the mean root diameter was significantly higher on coarse material $(6.3 \mathrm{~cm}$ versus $3.7 \mathrm{~cm}$; $\mathrm{P}<0.001)$. This difference was independent from TBD, as illustrated by the ratios between mean or largest root diameter and TBD, which were two to three times higher for coarse material. In fine material, mean root diameter did not increase with TBD over $25 \mathrm{~cm}$, never exceeding $5 \mathrm{~cm}$ (Fig. $5 \mathrm{a}$, table 3.c). Conversely, it increased significantly following a logarithmic trend in coarse material $\left(\mathrm{r}^{2}=0.53, \mathrm{P}<0.001\right)$, up to $9 \mathrm{~cm}$ for the largest trees. The diameter of the largest root by root system (Fig. 5b) was equal on both materials for small trees. It increased with TBD only for trees over $50 \mathrm{~cm}$ on fine material, far slower than on coarse material. Consequently, either for the mean or for the largest root diameter, the difference between coarse and fine material increased regularly with TBD and was significant over 30 and $40 \mathrm{~cm}$ respectively. We found no differences in the results with and without vertical roots, the average as well as the maximum root diameter being reduced by less than $5 \%$ when excluding vertical roots and in the same proportion for each material and species. 
The mean root diameter was not significantly different between root system types for a given material and similar TBD (Table 3d). It was significantly smaller for shallow root systems in fine material compared to coarse material, for small and intermediate TBD classes, varying consistently with the general difference between materials. The low numbers of mixed root systems on fine material did not allow a comparison with coarse material.

On coarse material, many poplars and locust, and some willows, developed a few very large roots per stump, sometimes out of proportion compared to the average of the system. The same trend could be found in fine material, but to a lesser extent. All roots over $30 \mathrm{~cm}$ in diameter were found on poplars stumps on coarse material. This trend is illustrated by the ratio of maximum/mean root diameter (Table $3 \mathrm{~b}$ ) which was $50 \%$ higher for poplars on coarse material and for poplars and locust on fine material. Other species did not present such a wide range of root diameter within a single root system whatever their size. Table $3 \mathrm{~b}$ presents values from small trees on coarse material, and large trees on fine material, respectively, for which all species could be compared. Results are similar for intermediate size trees, but all species were not found in this size class on both materials (data not shown).

Roots were shorter in fine than in coarse material (average of 127 versus $166 \mathrm{~cm}, \mathrm{P}<0.01$ ). This difference was strongly related (Table 3e) to root diameter decreasing rate (DDR): it was highly significant for roots with DDR < $3.1 \mathrm{~cm} / \mathrm{m}$ but not over this limit. No significant differences were found in length or decreasing rate between species or root system types, whatever the root type or size class. Taking all roots together, the ratio proximal root diameter/DDR was similar whatever the species (Fig. 6), material and root system type.

Table 3: Number and size of roots and root system volume according to root system type, soil material, species and $T B D$ classes $($ Large $=T B D>55 \mathrm{~cm}$, Medium $=45-55 \mathrm{~cm}$, Int $=35-45 \mathrm{~cm}$, Small $=25-35 \mathrm{~cm}$. Standard deviation is given between brackets.

3.a: Number of roots per root system type and material for all trees and different TBD classes

\begin{tabular}{|c|c|c|c|c|c|c|c|c|c|c|c|c|c|}
\hline \multicolumn{2}{|l|}{ 3.a } & \multicolumn{4}{|c|}{ All root system types } & \multicolumn{2}{|c|}{$\begin{array}{l}\text { Mixed \& tap } \\
\text { root systems }\end{array}$} & \multicolumn{2}{|c|}{$\begin{array}{c}\text { Shallow root } \\
\text { system }\end{array}$} & \multicolumn{4}{|c|}{ Heart shape root system } \\
\hline Material & TBD & Large & $\begin{array}{l}\text { Mediu } \\
\text { m }\end{array}$ & Int & Small & Int & Small & Int & Small & Large & $\begin{array}{l}\text { Mediu } \\
\mathrm{m}\end{array}$ & Int & Small \\
\hline Coarse & 42 & $\begin{array}{c}51 \\
(18.2)\end{array}$ & $\begin{array}{c}43 \\
(6.4)\end{array}$ & $\begin{array}{c}42 \\
(4.2)\end{array}$ & $\begin{array}{c}47 \\
(12.0)\end{array}$ & $\begin{array}{c}47 \\
(9.4) \\
\end{array}$ & $\begin{array}{c}49 \\
(9.8)\end{array}$ & $\begin{array}{c}36 \\
(10.9)\end{array}$ & $\begin{array}{c}31 \\
(8.7)\end{array}$ & na & na & na & na \\
\hline Fine & 58 & $\begin{array}{c}211 \\
(90.3)\end{array}$ & $\begin{array}{c}139 \\
(43.2)\end{array}$ & $\begin{array}{c}113 \\
(25.4)\end{array}$ & $\begin{array}{l}103 \\
(9.2)\end{array}$ & na & na & $\begin{array}{c}139 \\
(56.8)\end{array}$ & $\begin{array}{c}107 \\
(57.0)\end{array}$ & $\begin{array}{c}233 \\
(93.6)\end{array}$ & $\begin{array}{c}134 \\
(36.8)\end{array}$ & $\begin{array}{c}127 \\
(28.4)\end{array}$ & $\begin{array}{c}114 \\
(38.5)\end{array}$ \\
\hline
\end{tabular}

\begin{tabular}{|c|c|c|c|c|}
\hline $\begin{array}{c}\text { 3.B } \\
\text { Material } \\
\text { (tree size) }\end{array}$ & Species & $\begin{array}{l}\text { Root number } \\
\text { (SD) }\end{array}$ & $\begin{array}{c}\text { Root mean } \\
\text { diameter (cm) } \\
\text { (SD) }\end{array}$ & $\begin{array}{l}\text { Ratio largest } \\
\text { /mean diam } \\
\text { (SD) }\end{array}$ \\
\hline \multirow{4}{*}{$\begin{array}{l}\text { Coarse } \\
\text { (small } \\
\text { trees) }\end{array}$} & Poplars & $\begin{array}{c}40 \\
(11.2)\end{array}$ & $\begin{array}{c}6.2 \\
(0.98)\end{array}$ & $\begin{array}{c}4.5 \\
(0.98)\end{array}$ \\
\hline & Loccust & $\begin{array}{c}54 \\
(10.8)\end{array}$ & $\begin{array}{c}5.6 \\
(0.94)\end{array}$ & $\begin{array}{c}2.4 \\
(0.58)\end{array}$ \\
\hline & Ash & $\begin{array}{c}38 \\
(11.8)\end{array}$ & $\begin{array}{c}5.5 \\
(0.64)\end{array}$ & $\begin{array}{c}2.5 \\
(0.57)\end{array}$ \\
\hline & Oak & $\begin{array}{c}38 \\
(6.4)\end{array}$ & $\begin{array}{c}6.2 \\
(0.80)\end{array}$ & $\begin{array}{c}2.2 \\
(0.26)\end{array}$ \\
\hline \multirow{6}{*}{$\begin{array}{l}\text { Fine } \\
\text { (large } \\
\text { trees) }\end{array}$} & Poplars & $\begin{array}{c}205 \\
(81.3)\end{array}$ & $\begin{array}{c}3.5 \\
(0.49)\end{array}$ & $\begin{array}{c}6.8 \\
(2.53)\end{array}$ \\
\hline & Loccust & $\begin{array}{c}196 \\
(102.2)\end{array}$ & $\begin{array}{c}3.8 \\
(0.28)\end{array}$ & $\begin{array}{c}6.1 \\
(3.83)\end{array}$ \\
\hline & Ash & $\begin{array}{c}169 \\
(109)\end{array}$ & $\begin{array}{c}4.0 \\
(0.46)\end{array}$ & $\begin{array}{c}4.3 \\
(1.20)\end{array}$ \\
\hline & Oak & $\begin{array}{l}160 \\
(64)\end{array}$ & $\begin{array}{c}3.7 \\
(0.51)\end{array}$ & $\begin{array}{c}4.1 \\
(1.70)\end{array}$ \\
\hline & Maple & $\begin{array}{l}141 \\
(49)\end{array}$ & $\begin{array}{c}3.3 \\
(1.06)\end{array}$ & $\begin{array}{c}4.3 \\
(0.35)\end{array}$ \\
\hline & Willow & $\begin{array}{l}143 \\
(60)\end{array}$ & $\begin{array}{c}4.1 \\
0.81)\end{array}$ & $\begin{array}{c}4.8 \\
(1.6)\end{array}$ \\
\hline
\end{tabular}

3.b: Root number, mean and largest root diameter per root system according to species, for small trees on coarse material and for large trees on fine material. Values in bold are significantly different from others for a given material. 
3.c: Mean root diameter per root system type and material for different TBD classes

\begin{tabular}{|c|c|c|c|c|c|c|c|c|c|c|}
\hline \multirow[t]{2}{*}{ 3.c } & \multicolumn{4}{|c|}{ Mean root diameter $(\mathrm{cm})$} & \multirow{2}{*}{$\begin{array}{c}\text { Ratio mean } \\
\text { root diam / } \\
\text { TBD } \\
\text { All trees }\end{array}$} & \multirow{2}{*}{$\begin{array}{c}\text { Ratio } \\
\text { largest root } \\
\text { diam / TBD } \\
\text { All trees }\end{array}$} & \multicolumn{4}{|c|}{ Mean root system volume $\left(\mathrm{m}^{3}\right)$} \\
\hline & All trees & Medium & Int & Small & & & All trees & Medium & Int & Small \\
\hline $\begin{array}{c}\text { Coarse } \\
\text { material }\end{array}$ & $\begin{array}{c}6.3 \\
(1.36)\end{array}$ & $\begin{array}{c}8.1 \\
(1.07)\end{array}$ & $\begin{array}{c}7.2 \\
(1.48)\end{array}$ & $\begin{array}{l}5.68 \\
0.58)\end{array}$ & $\begin{array}{c}0.22 \\
(0.06)\end{array}$ & $\begin{array}{c}0.69 \\
(0.23)\end{array}$ & $\begin{array}{c}8.7 \\
(6.49)\end{array}$ & $\begin{array}{c}18.1 \\
(3.40)\end{array}$ & $\begin{array}{c}13.1 \\
(6.56)\end{array}$ & $\begin{array}{c}9.3 \\
(5.74)\end{array}$ \\
\hline $\begin{array}{c}\text { Fine } \\
\text { material }\end{array}$ & $\begin{array}{c}3.7 \\
(0.79)\end{array}$ & $\begin{array}{c}3.8 \\
(0.87)\end{array}$ & $\begin{array}{c}3.7 \\
(0.95)\end{array}$ & $\begin{array}{c}3.7 \\
(1.08)\end{array}$ & $\begin{array}{c}0.08 \\
(0.04)\end{array}$ & $\begin{array}{c}0.39 \\
(0.19)\end{array}$ & $\begin{array}{c}8.7 \\
(4.20)\end{array}$ & $\begin{array}{c}7.94 \\
(4.28)\end{array}$ & $\begin{array}{c}6.8 \\
(4.86)\end{array}$ & $\begin{array}{c}4.55 \\
(1.70)\end{array}$ \\
\hline
\end{tabular}

3.d: Mean root diameter, root system volume and ratio mean and maximum root diameter / TBD for coarse and fine material

\begin{tabular}{|ccccccc|}
\hline 3.d & \multicolumn{7}{c|}{ Root System Type } \\
\hline & Mixed and Tap & \multicolumn{2}{c|}{ Shallow } & \multicolumn{2}{c|}{ Heart } \\
\hline & Int & small & Int & Small & Int & Small \\
\hline Coarse & 6,8 & 6,6 & 6,0 & 5,6 & & \\
material & $(1,22)$ & $(1,20)$ & $(1,70)$ & $0,46)$ & & \\
\hline Fine & & & 3,7 & 2,5 & 3,4 & 3,4 \\
material & & & $(0,97)$ & $(0,62)$ & $(0,26)$ & $(0,91)$ \\
\hline
\end{tabular}

3.e: Mean root length $(\mathrm{cm})$ and decreasing rate $(\mathrm{cm} / \mathrm{m})$ according to two types of roots and material. The probability is given for the difference between fine and coarse material. $N S=$ non significant $(P>0.05)$.

\begin{tabular}{|lccccc|}
\hline \multicolumn{1}{|c}{ 3.e } & \multicolumn{3}{c|}{ Diameter Decrease Rate (DDR) } \\
\hline & & $\mathrm{DDR}<3.1 \mathrm{~cm} / \mathrm{m}$ & \multicolumn{1}{c|}{ DDR $>3.1 \mathrm{~cm} / \mathrm{m}$} \\
\hline & Proximal root diameter & $5-10 \mathrm{~cm}$ & $2-5 \mathrm{~cm}$ & $5-10 \mathrm{~cm}$ & $2-5 \mathrm{~cm}$ \\
\hline $\begin{array}{l}\text { Mean root length } \\
(\mathbf{c m})\end{array}$ & Fine material & 229 & 106 & 113 & 60 \\
\hline Proba root length & Coarse material & 333 & 174 & 95 & 63 \\
\hline
\end{tabular}

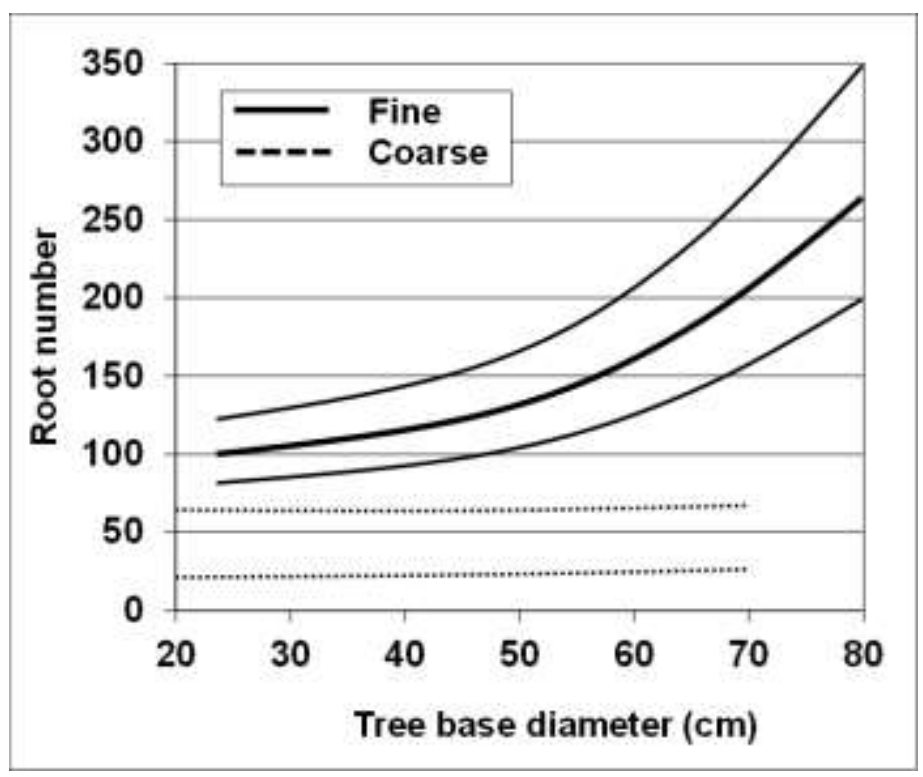

Figure 4: Relationship in bold line between root number per root system and tree base diameter according to soil material. Thin upper and lower lines = span of observations. Root number higher in fine material than in coarse material. 
Figure 5: Relationship in bold lines between (5a) root system mean root diameter or (5b) diameter of root system largest root and tree base diameter according to soil material. Thin upper and lower lines = span of observations. Mean and Max root diameter higher in coarse material than in fine material.

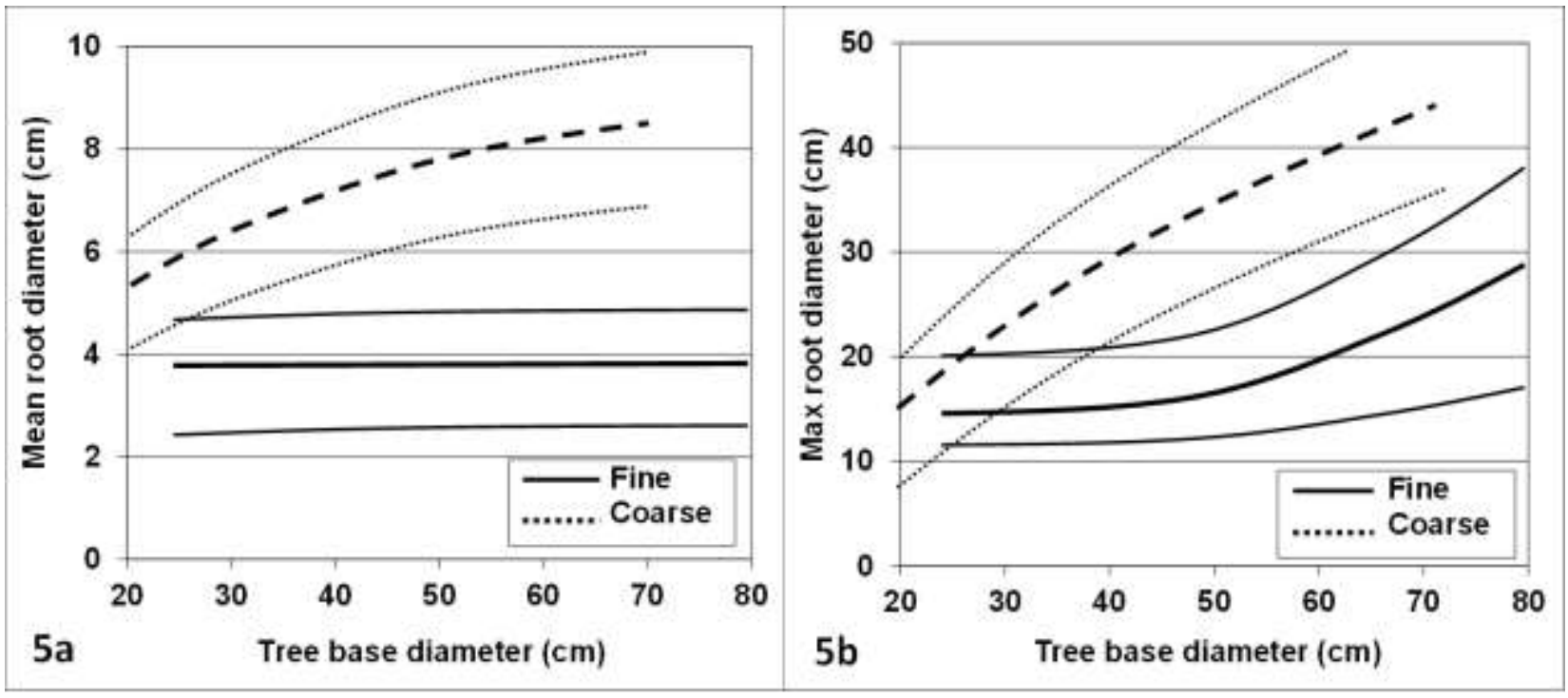

Figure 6: Relationship between root diameter decrease rate $(\mathrm{cm} / \mathrm{m})$ and root proximal diameter $(\mathrm{cm})$ by species all roots together and by material (logarithm scale; $-1=0.1 \mathrm{~cm}$ and $1=10 \mathrm{~cm}$ ). No significant differences between species nor between material

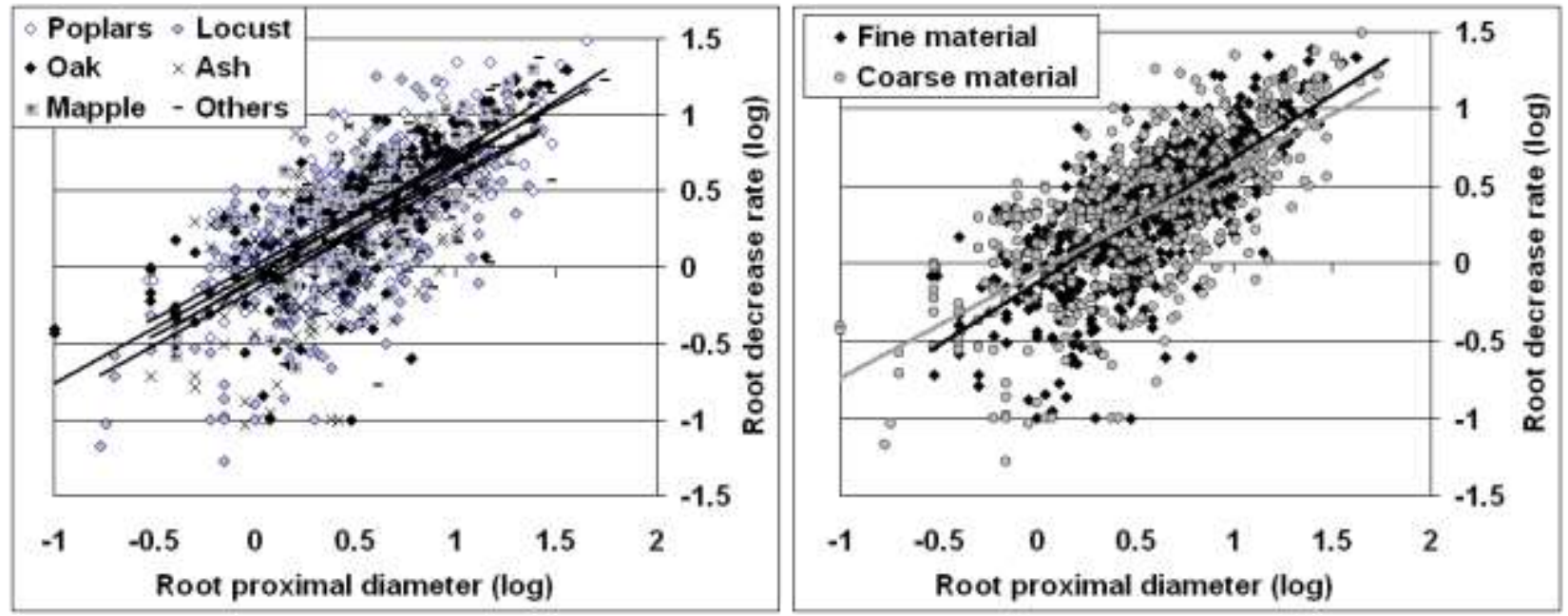

\section{4 - Root system volume according to material and root system type}

Root system volume varied from 3 to $8 \mathrm{~m}^{3}$ for small trees and from 6 to $22 \mathrm{~m}^{3}$ for the largest ones (Table $3 \mathrm{c}$ ). Root system volume was only weakly correlated with TBD or tree age on the whole sample $\left(\mathrm{r}^{2}=0.3, \mathrm{P}<0.01\right)$ due to the differences between root system types and material. The correlation with TBD was good for shallow root systems $\left(\mathrm{r}^{2}\right.$ $=0.80)$, and remained significant, although far weaker, for mixed and tap root systems $\left(\mathrm{r}^{2}=0.53\right)$ and heart root systems $\left(r^{2}=0.47\right)$. For the same class of TBD, $(30-35 \mathrm{~cm})$ shallow root systems averaged about $50 \%$ of the volume of mixed root system ( 5.4 versus $\left.10.5 \mathrm{~m}^{3}, \mathrm{p}=0.025\right)$; the same difference was observed when combining tap root and mixed root systems. Heart root systems had about the same mean volume as mixed root systems $\left(10\right.$ and $10.8 \mathrm{~m}^{3}$ resp.), although their average TBD was much larger $(61$ versus $34 \mathrm{~cm})$. Thus heart root systems seemed to have a far smaller spatial development, consistent with their shorter roots. These differences between root system types may be linked to material, because heart root systems were found only on fine materials while mixed and tap root systems developed mainly on coarse material. Root system mean volumes were identical on fine and coarse materials (8.7 $\mathrm{m}^{3}$ ), whereas the average TBD was by far larger on fine material $(58$ versus $42 \mathrm{~cm})$.

For trees which had been coppiced once or several times, root system volume depended mainly on stump age and not on TBD for given material and species. However stump age was rarely known for trees coppiced several times and on old dikes, so no precise relation could be established. 


\section{5 - Influence of slope and water resources}

As a whole, root number was higher downslope than upslope (67 versus $53, \mathrm{p}=0.025$ ). However, only $57 \%$ of the trees had a higher root number downwards (mean difference in root number $=+67 \%$ ) while $25 \%$ had a higher root number upward with a smaller mean difference $(+21 \%)$ and $18 \%$ the same number $( \pm 10 \%)$.

Root systems with a privileged access to water were asymmetric. The largest roots systematically developed in the direction of the closest water resource when available, thus downslope to reach a water channel or vertically (taproots) to reach the water table. The mean root diameter was 65\% larger downslope or vertically than upslope (P< 0.001). In coarse material, such roots reaching a permanent water resource were larger, from $2-3$ times $(\mathrm{P}<0.001)$, than the mean diameter of other large roots. Mixed or tap root systems were found in coarse material when water or nutrient resources were less than $3 \mathrm{~m}$ in depth. The largest vertical roots (proximal diameter up to $40-60 \mathrm{~cm}$ ) were found in such conditions on poplar stumps.

Climate influenced these general patterns. On the crown and upper slopes of the Castérino dike, a large dike made of coarse material in a cold and humid mountain climate, all seven trees had one or several taproots and several other roots growing throughout the embankment. The permanent availability of water in the fill attenuated the upward/downward dissymmetry and allowed vertical roots to develop through the coarse material. Conversely on the Donzère and Montélimar dikes in a Mediterranean climate with a long summer drought, 95\% of the trees (35/37) growing at the same position on the dike had shallow root system and the dissymmetry was more pronounced.

With only one exception (alder), roots never penetrated more than a few centimetres in permanent water tables. Root penetration was also limited in hydromorphic horizons, all the more since the hydromorphy was severe. Thus, root systems were often shallow close to the toe of canal dikes or on the lower banks of rivers, being limited in depth by a permanent or temporary water table. In fine material (pseudogleys) at dike toes, old poplars developed dozens of small vertical roots (sinkers) 5 to $15 \mathrm{~cm}$ in diameter and up to $2 \mathrm{~m}$ long, growing out from horizontal roots, densely lining up into soil cracks. These additional roots were found mainly under the stump and in a radius of three metres around it. They contributed to increase considerably the volume of these root systems and made them difficult to extract.

\section{4 - Discussion}

Root system structure results from an interaction between genetic heritage and environmental constraints (Atger, 1991; Köstler et al., 1968). In this study, however, the type of soil material was one of the strongest environmental factors influencing root system structure. In coarse materials, trees develop only few roots but they are large and rather long, whereas fine materials favour denser systems with smaller diameters (less than $5 \mathrm{~cm}$ ) and shorter roots (mean length $<2 \mathrm{~m}$ ). Roots tend to proliferate in nutrient-rich pockets and horizons when the soil is heterogeneous (George et al., 1997; Hodge, 2004). In fine materials, roots multiplied over a TBD of $25 \mathrm{~cm}$ while the mean root diameter was stable and the maximum root diameter increased slowly. This finding suggests either that trees produce continuously new roots in the core of the root system, directly on the stump and from older roots, or that pre-existing small roots are slowly growing in length and diameter. These new small roots reaching the minimum size limit $(2 \mathrm{~cm})$ can compensate for the growth of the older ones, stabilizing the mean root diameter. Such developmental instability is considered as an adaptive trait (Forde, 2009), useful for plasticity to be able to respond to potentially changing conditions. The permanent production of roots is possible thanks to the absence of strong constraints from the environment. The presence of abundant resources (nutrients and water) in fine materials allows trees to feed in a small volume around the stump. This may explain the reduced length and depth of roots as observed by Tatarinov et al. (2008) on clayey alluvial soils: the average radius of root systems for large oaks and ash trees with diameters up to $65 \mathrm{~cm}$ were smaller than seven metres. The sharing between many roots, of soil resources in a small volume around the stump, as well as of energy and substances elaborated in the crown, probably contributes to the limited root diameter in these systems.

In water or nutrient-limited environments, particularly those with little organic matter, in sandy soils or in arid climates, tree root systems tend to be large compared to aerial parts, and they reach greater depths (Schenk et al., 2002). In Mediterranean forests, Quercus ilex L. develops roots up to $33 \mathrm{~m}$-long spanning up to seven times the surface of its canopy (Moreno et al., 2005). Accordingly in dikes made of coarse material, the root system span was far higher and vertical roots were longer and larger than in fine materials. In coarse materials, resources are limited and sometimes far from the stump, particularly on large and thick fills. Moreover, on very coarse material, root length and diameter growth is physically constrained by pebbles, stones and blocks, obliging the growing roots to skirt around hundreds of obstacles and worm their way into narrow and winding chinks. However, roots are able to take advantage of small pockets of better soil and to adapt at small scale to substrate heterogeneity (Desnos, 2008), while sending remote signals to the plant to favour their development (Forde et al., 2001). It could be hypothesized that roots probably explore and exploit most of the rare possible routes close to the stump from the very beginning of tree settlement, and only the few successful ones finding water or nutrient resources survive and develop. As most of the supplying of the tree depends on these few roots, they drain all resources from the soil but also those coming from the crown, and grow rapidly. This may be especially true for vertical roots or long shallow roots which have reached a 
water resource, and become out of proportion compared to other main roots. In such conditions, it would be difficult for new roots to encounter additional resources or unexplored routes. Thus, in contrast to fine material, the root number remains stable with tree size, while mean and maximum root diameter increase rapidly with TBD.

The position of a tree on the dike and dike size act on two parameters which influence root system structure: slope and access to water and nutrient resources. On slopes, roots are generally more numerous and larger upwards in order to secure tree anchoring (Di Iorio et al., 2005; Nicoll et al., 2006a; Schwarz et al., 2010). In this study, this general pattern was rarely observed, due to the fact that resources were unevenly distributed around the stump. The presence of a channel, river or water table, a layer of fine and richer materials under a coarse fill, and natural soil easy to reach at dike toe clearly bias root system development towards the richest and wettest targets downslope. This result is consistent with observations on experimental irrigation or fertilization devices (George et al., 1997; Soar et al., 2007; Sokalska et al., 2009) that show a strong asymmetry in root system development in the direction of resources.

Many tree species are able to explore the soil and rock layers deeper than $5 \mathrm{~m}$ and for some of them as far as $20 \mathrm{~m}$ (Canadell et al., 1996). Deep rooting depths are generally found in water-limited environments (Schenk et al., 2002), particularly those with little organic matter, in sandy soils or in arid climates. Surprisingly in this study, root systems on coarse materials were of mixed or taproot types only when trees had a vertical access to a water table or to a more humid layer at less than $3 \mathrm{~m}$ in depth. However, deep rooting depth was reported in the literature mainly for natural old stands (Köstler et al., 1968; Plourde et al., 2009). Indeed, most of the largest and highest dikes of this study, where the $3 \mathrm{~m}$ limit appeared, are less than 100-years old and often much younger. Such a short time may have limited the ability for roots to find all possible routes or to take advantage of an especially long humid period to cross the critical 1-3 m depth. In fact, very deep rooting seems possible in materials and soils where roots can find some resources and particularly water all along their way down, for example, in the cracks of a karst (Jackson et al., 1999). On the crown and upper slope of large dikes or river banks made of coarse, well-drained materials, there are no vertically accessible nutrient resources and the heart of the dike is extremely dry in summer. Accordingly, Devine et al. (2005) found only shallow root systems for Oregon white oak on coarse and poor glacial outwash soils, one of the rare studies on coarse material similar to that of some dike fills. As shown by the presence of small vertical roots (initial taproot) on the youngest stumps and their remainder in older ones, vertical roots appear at an early stage of root system development, which is common for many species (Köstler et al., 1968), but remain weak or abort later as they cannot find good growing conditions or water in depth (Hipondoka et al., 2006). Conversely, shallow roots may take advantage of rain water, of fine material deposits at soil surface or of a superficial humus layer formed by vegetation. Moreover, physical constraints may be partially released close to the surface, where roots can more easily move stones while they grow in diameter.

On fine materials the position of trees on the dike seems much less important for root system structure. Resources are more regularly distributed and root development has no severe constraints in any direction. However, permanent water resources also lead to asymmetric development of root systems.

The tap root systems were scarce in this study as well as in the literature (Köstler et al., 1968). Indeed, even when they develop one or several large vertical roots, trees generally produce a set of significant shallow roots to secure their anchoring, especially for support against wind (Danjon et al., 2005; Kamimura et al., 2012; Nicoll et al., 2006a; Tamasi et al., 2005), and to extract nutrients. Sheer tap root systems tend to occur only when a lack of shallow resources is combined with a permanent deep water table.

Roots of most tree species cannot develop directly in a permanent water table, as abundantly documented in the scientific literature (Imada et al., 2008; Nieuwenhuis et al., 2003). The higher proportion of shallow systems on fine material for alder and willow compared to other species in this study is explained by their natural trend to grow very close to the river or canal, and therefore to the water table. Root development is also strongly constrained by soil compaction as well as hard pan layers, presenting unfavourable mechanical proprieties (Danjon et al., 2009; Unger et al., 1994). Accordingly, shallow root systems were found irrespective of the material when a permanent or semipermanent water table existed in the first $50 \mathrm{~cm}$ or when dike structure included a compacted silty or clayey core. Each species has a specific tolerance to hydromorphy. Poplars proved to be able to colonize part of a pseudogley up to $2 \mathrm{~m}$ in depth, with dozens of small or medium-size vertical roots filling and following cracks. Such root systems should be considered as a specific type, very different from the typical mixed root systems with only one or a few large taproots. Although the soil initially presents less anoxic conditions along these cracks thanks to evaporation, water uptake by the roots entering these cracks may rapidly contribute to expand the width of the desiccation zone around the cracks and, as a feedback, accelerate their colonisation by roots. Unfortunately, the studied sites offered no opportunities to study root system development of other species in the same conditions.

Root system volume is partly linked to the development of its main roots (Table 3c). The good correlation between volume and TBD for shallow root systems can be explained by the direct relation between the area colonized by roots at low depth and root system volume. Shallow root systems logically have a smaller volume than mixed ones because the latter have similar long shallow roots but they have large and long vertical roots also. Heart root systems and root systems on fine material have a smaller volume than mixed root systems or those on coarse material, because of the reduced root length. Similar differences in root plate volume and span according to root system type were found by 
Ray et al. (1998) in Sitka spruce uprooting experiments. Root system volume also depends on the distribution of small and fine roots, which can be highly irregular, leaving large gaps between main roots (Tatarinov et al., 2008). As tree anchorage is strongly linked to these characteristics, measuring them more precisely may allow assessing the volume of the root plate which could be lifted when the tree is uprooted, this volume varying with material types and soil humidity (Kamimura et al., 2012).

Root length is significantly correlated to root proximal diameter (Table 3e), as already found in other contexts (Van Noordwijk et al., 1994). Thus, for a given environment and soil material, a validated and calibrated predictive relationship could be used to infer the potential root length from a simple proximal diameter measure close to the tree without fully extracting the stump. As diameter decreasing rates are significantly different between fine and coarse materials, variations in soil composition must be taken into account for a practical use of this relation in field expertise. A detailed analysis of individual root architecture recently confirmed the influence of material on root length and decreasing rate (Vennetier et al., in press) as well as on other architectural characteristics as branching patterns. Long roots with low decreasing and branching rates and short roots with higher values for these two parameters were identified. This may help for recognizing contrasting root types close to the stump. However, the proportion of such root types is unknown for a given root system, and it is difficult to determine except close to the soil surface. Thus assessing root potential length from proximal diameter may only be possible for the root system as a whole, not for all individual roots.

\section{5 - Conclusion and prospects}

The global structure of tree root systems seems opportunistic, mainly influenced by environmental conditions, and particularly by soil material, and to a lesser extent by the tree species. This architectural plasticity offers trees a high capacity of adaptation to various conditions. This study gives a new insight in root development: it will help predict tree root growth in various environments and more specifically on dikes. Material type and water availability allow to presage root system structure.

Although these results are reliable, based on one of the largest set of trees and species ever extracted to study root systems, they focus on locally homogeneous and quite deep soils. The response of tree species to more heterogeneous or extreme conditions or with severe physical or chemical constraints may have been more contrasting due to the specific tolerance of some species to these constraints. Additional research is required to confirm them in other environments, on other soil materials, and for other species.

\section{ACKNOWLEDGEMENTS}

This study was funded by IRSTEA, Provence Alpes Côte d'Azur region, French National Research Agency (ANRERINOH project), by European Union (Interreg IV A France-Suisse 2007-2013) and by dike managers (EDF, CNR, AD Isère-Drac-Romanche, DDT Nièvre, SMAVD, Chambery Métropole, Conseil Général de l'Isère) who hired the technical staff and material to log trees, extract root systems and remediate damages to studied sites. The authors are indebted to many colleagues, technicians and students who contributed in data collection during sometimes difficult field campaigns, and particularly to Willy Martin, Roland Estève, Olivier Chandioux, Gaylord Doirat, Pierre Jean Moundy and David Fiorese. They thank several anonymous reviewers for their useful suggestions, as well as Maureen K. Corcoran and Pete Fulé for their comments, corrections and their help in language editing.

\section{REFERENCES}

Akinnifesi FK, Smucker AJM, Kang BT (1999) Below-ground dynamics in agroforestry systems. Ann Arid Zone, vol. 38, n 3-4, p. 239-273.

Armengaud P, Zambaux K, Hills A, Sulpice R, Pattison RJ, Blatt MR, Amtmann A (2009) EZ-Rhizo: integrated software for the fast and accurate measurement of root system architecture. Plant J, vol. 57, $\mathrm{n}^{\circ}$ 5, p. 945-956.

Atger C (1991) L'architecture racinaire est-elle influencée par le milieu? L'arbre, biologie et developpement, $n^{\circ}$ hs, $p$. 71-84.

Atger C, Edelin C (1994) Premières données sur l'architecture comparée des systèmes racinaires et caulinaires. Can J Bot, $\mathrm{n}^{\circ} 72$, p. 963-975.

Canadell J, Jackson RB, Ehleringer JR, Mooney HA, Sala OE, Schulze ED (1996) Maximum rooting depth of vegetation types at the global scale. Oecologia, vol. 108, ${ }^{\circ} 4$, p. 583-595.

Corcoran M (2009) The Effects of Woody Vegetation on Levee Performance. in US-ARMY (ed) USSD Workshop on Levees, Sacramento, California.

Danjon F, Fourcaud T, Bert R (2005) Root architecture and wind-firmness of mature Pinus pinaster. New Phyto, vol. 168, p. 387-400.

Danjon F, Fourcaud T (2009) L'arbre et son enracinement. Innov Agron, vol. 6, p. 17-37.

Danjon F, Fourcaud T, Bert D (2005) Root architecture and wind-firmness of mature Pinus pinaster. New Phytol, vol. $168, \mathrm{n}^{\circ} 2$, p. $387-400$ 
Danjon F, Reubens B (2008) Assessing and analyzing 3D architecture of woody root systems, a review of methods and applications in tree and soil stability, resource acquisition and allocation. Plant Soil, vol. 303, $\mathrm{n}^{\circ} 1-2$, p. 1-34.

Desnos T (2008) Root branching responses to phosphate and nitrate. Curr Opin Plant Biol, vol. 11, nº 1, p. 82-87.

Devine WD, Harrington CA (2005) Root system morphology of Oregon white oak on a glacial outwash soil. Northwest Sci, vol. 79, $\mathrm{n}^{\circ}$ 2-3, p. 179-188.

Di Iorio A, Lasserre B, Scippa GS, Chiatante D (2005) Root system architecture of Quercus pubescens trees growing on different sloping conditions. Ann Bot, vol. 95, n 2, p. 351-361.

Eis S (1974) Root system morphology of Western Hemlock, Western Red Cedar, and Douglas-Fir. Can J Forest Res, $\mathrm{n}^{\circ} 4$, p. $28-38$

Fitter A, Stickland T (1991) Architectural analysis of plant root systems 2. Influence of nutrient supply on architecture in contrasting plant species. New Phytol, vol. 118, p. 383-389.

Fitter AH (1994) Architecture and biomass allocation as components of the plastic response of root system to soil heterogeneity. In: Exploiting of environnemental heterogeneity by plants, (ed Caldwell M.M.a.P.R.W.), Academic Press, San Diego New York Boston London Sydney Tokyo Toronto, p. 305-323.

Forde B, Lorenzo H (2001) The nutritional control of root development. Plant Soil, vol. 232, n 1-2, p. 51-68.

Forde BG (2009) Is it good noise? The role of developmental instability in the shaping of a root system. J Exp Bot, vol. $60, \mathrm{n}^{\circ} 14$, p. 3989-4002.

Foussadier R (2003) Les systèmes racinaires des arbres de la ripisylve : effets des contraintes physiquues et exemples. In: Les forêts riveraines des cours d'eau, écologie, fonctions et gestion, (ed IDF), Paris, p. 124-133.

George E, Seith B, Schaeffer C, Marschner H (1997) Responses of Picea, Pinus and Pseudotsuga roots to heterogeneous nutrient distribution in soil. Tree Physiol, vol. 17, $\mathrm{n}^{\circ}$ 1, p. 39-45.

Haselsteiner R (2010) Woody Vegetation on Small Embankment Dams. In: Proc. 8th ICOLD European Club Symposium on dam safety, Innsbruck, Austria, September 22-23, 2010, p. 381-386.

Hipondoka MHT, Versfeld WD (2006) Root system of Terminalia sericea shrubs across rainfall gradient in a semiarid environment of Etosha National Park, Namibia. Ecol Indic, vol. 6, n 3, p. 516-524.

Hodge A (2004) The plastic plant: root responses to heterogeneous supplies of nutrients. New Phytol, vol. 162, ${ }^{\circ} 1$, p. 9-24.

Imada S, Yamanaka N, Tamai S (2008) Water table depth affects Populus alba fine root growth and whole plant biomass. Funct Ecol, vol. 22, n 6 , p. 1018-1026.

Jackson RB, Moore LA, Hoffmann WA, Pockman WT, Linder CR (1999) Ecosystem rooting depth determined with caves and DNA. Proceedings of the National Academy of Sciences of the United States of America, vol. 96, $\mathrm{n}^{\circ}$ 20, $\mathrm{p}$. 11387-11392.

Jourdan C, Rey H (1997) Architecture and development of the oil-palm (Elaeis guineensis Jacq) root system. Plant Soil, vol. $189, \mathrm{n}^{\circ} 1$, p. 33-48.

Kamimura K, Kitagawa K, Saito S, Mizunaga H (2012) Root anchorage of hinoki (Chamaecyparis obtuse (Sieb. Et Zucc.) Endl.) under the combined loading of wind and rapidly supplied water on soil: analyses based on tree-pulling experiments. Eur J Forest Res, vol. 131, nº 1, p. 219-227.

Köstler JN, Brueckner E, Bibelriether H (1968) Die Wurzeln der Waldbäume. Untersuchung zur Morphologie der Waldbäume in Mitteleuropa., Paul Parey, Hamburg.

Moreno G, Obrador JJ, Cubera E,Dupraz C (2005) Fine root distribution in Dehesas of Central-Western Spain. Plant Soil, vol. 277, $\mathrm{n}^{\circ} 1-2$, p. 153-162.

Nemenyi PB (1963) Distribution-free multiple comparisons. Princeton University, New Jersey.

Nicoll BC, Berthier S, Achim A, Gouskou K, Danjon F, Van Beek LPH (2006a) The architecture of Picea sitchensis structural root systems on horizontal and sloping terrain. Trees-Structure Funct, vol. 20, n 6, p. 701-712.

Nicoll BC, Gardiner BA, Rayner B, Peace AJ (2006b) Anchorage of coniferous trees in relation to species, soil type, and rooting depth. Can J Forest Res, vol. 36, $\mathrm{n}^{\circ}$ 7, p. 1871-1883.

Nieuwenhuis M, Wills J, Gardiner J, Sundstrom E, Keane M (2003) The effect of soil cultivation methods on rooting depth of young Sitka spruce (Picea sitchensis (Bong.) Carr.) trees on wet mineral soils in Ireland. Forestry, vol. 76, ${ }^{\circ}$ 4, p. 465-477.

Plourde A, Krause C, Lord D (2009) Spatial distribution, architecture, and development of the root system of Pinus banksiana Lamb. in natural and planted stands. Forest Ecol Manag, vol. 258, n 9, p. 2143-2152.

Ray D, Nicoll BC (1998) The effect of soil water-table depth on root-plate development and stability of Sitka spruce. Forestry, vol. 71, $\mathrm{n}^{\circ} 2$, p. 169-182.

Reubens B, Poesen J, Danjon F, Geudens G, Muys B (2007) The role of fine and coarse roots in shallow slope stability and soil erosion control with a focus on root system architecture: a review. Trees-Struct Funct, vol. 21, $\mathrm{n}^{\circ} 4$, p. 385-402. 
Rood S, Bigelow S, Hall A (2011) Root architecture of riparian trees: river cut-banks provide natural hydraulic excavation, revealing that cottonwoods are facultative phreatophytes. Trees - Struct funct, vol. 25, $n^{\circ}$ 5, p. $907-917$.

Schenk H, Jackson R (2005) Mapping the global distribution of deep roots in relation to climate and soil characteristics. Geoderma, vol. 126, p. 129-140.

Schenk HJ, Jackson RB (2002) The global biogeography of roots. Ecol Monog, vol. 72, n 3, p. 311-328.

Schwarz M, Lehmann P (2010) Quantifying lateral root reinforcement in steep slopes - from a bundle of roots to tree stands. Earth Surf Proc Land, vol. 35, n 3, p. 354-367.

Shields FD, Gray DH (1992) Effects of woody vegetation on the structural integrity of sandy levees. Water Resour Bull, n 28, p. 917-931.

Soar CJ, Loveys BR (2007) The effect of changing patterns in soil-moisture availability on grapevine root distribution, and viticultural implications for converting full-cover irrigation into a point-source irrigation system. Aust J Grape and Wine Res, vol. 13, $\mathrm{n}^{\circ}$ 1, p. 2-13.

Sokalska DI, Haman DZ, Szewczuk A, Sobota J, Deren D (2009) Spatial root distribution of mature apple trees under drip irrigation system. Agr Water Manag, vol. 96, n 6, p. 917-924.

Stone EL, Kalisz PJ (1991) On the maximum extent of tree roots. Forest Ecol Manag, n 46, p. 59-102.

Sutton RF, Tinus RW (1983) Root and root system terminology. Soc American Forest, Bethesda (USA), 137 p.

Tamasi E, Stokes A, Lasserre B, Danjon F, Berthier S, Fourcaud T, Chiatante D (2005) Influence of wind loading on root system development and architecture in oak (Quercus robur L.) seedlings. Trees-Struct Funct, vol. 19, $\mathrm{n}^{\circ} 4$, p. 374-384.

Tatarinov F, Urban J, Cermak J (2008) Application of "clump technique" for root system studies of Quercus robur and Fraxinus excelsior. Forest Ecol Manag, vol. 255, n 3-4, p. 495-505.

Tobin B, Cermak J, Chiatante D, Danjon F, Di Iorio A, Dupuy L, Eshel A, Jourdan C, Kalliokoski T, Laiho R, Nadezhdina N, Nicoll B, Pages L, Silva J, Spanos I (2007) Towards developmental modelling of tree root systems. Plant Biosystems, vol. 141, n 3, p. 481-501.

Unger PW, Kaspar TC (1994) Soil Compaction and Root Growth: A Review. Agro J, vol. 86, p. 759-766.

Vannoordwijk M,Spek LY, Dewilligen P (1994) Proximal root diameter as predictor of total root size for fractal branching models. 1. Theory, Plant Soil, vol. 164, $\mathrm{n}^{\circ}$ 1, p. 107-117.

Vennetier M, Zanetti C, Mériaux P, Mary B (in press) Tree root architecture: new insights from a comprehensive study on dikes », Plant Soil (DOI 10.1007/s11104-014-2272-9).

Vercambre G, Pages L, Doussan C, Habib R (2003) Architectural analysis and synthesis of the plum tree root system in an orchard using a quantitative modelling approach. Plant Soil, vol. 251, $\mathrm{n}^{\circ}$ 1, p. 1-11.

Vyskot M (1976) Tree Story Biomass in Lowland Forests in South Moravia. Rozpravy CSAV, Academia, Praha., vol. $86, \mathrm{n}^{\circ} 10$.

Wagner B, Gärtner H, Santini S, Ingensand H (2011) Cross-sectional interpolation of annual rings within a 3D root model. Dendrochronologia, vol. 29, n 4, p. 201-210.

Zanetti C (2010) Characterization of tree root systems in earth dikes, PHD Dissertation, Cemagref, Provence University, p.197. 